\title{
WPŁYW SPOSOBU PIELĘGNACJI NA WYBRANE WŁAŚCIWOŚCI BETONU
}

\author{
Jacek Szpetulski ${ }^{\bowtie}$ \\ Wydział Budownictwa, Mechaniki i Petrochemii, Politechnika Warszawska, Płock
}

\begin{abstract}
STRESZCZENIE
Sposób pielęgnacji przyczynia się do zmiany struktury betonu, a w wyniku tego zmieniają się jego właściwości. W pracy przedstawiono wpływ trzech różnych sposobów pielęgnacji na właściwości betonu. Do oceny wpływu sposobu pielęgnacji betonu wykonano badania wytrzymałości na ściskanie, wnikanie chlorków w beton, karbonatyzacji, nasiąkliwości i sorpcyjności masowej. Na podstawie wykonanych badań stwierdzono, że pielęgnacja betonu w warunkach o małej wilgotności na poziomie $53 \%$ powoduje w dużym stopniu pogorszenie właściwości betonu.
\end{abstract}

Słowa kluczowe: pielęgnacja betonu, wytrzymałości na ściskanie, wnikanie chlorków w beton, karbonatyzacja, nasiąkliwość, sorpcyjność

\section{WSTĘP}

Beton w konstrukcji żelbetowej przenosi naprężenia ściskające i pełni funkcję otuliny ochronnej dla stali. Funkcja otuliny ochronnej wynika z zasadowego charakteru betonu, która powoduje powstanie warstwy pasywnej na zbrojeniu i przeciwdziała powstaniu procesu korozji prętów zbrojeniowych (Ściślewski, 1999; Jamroży, 2015). Jednak pod wpływem działania agresywnego środowiska wraz z upływem czasu zachodzą procesy korozyjne w betonie, które prowadzą do zmiany jego zasadowego charakteru. W konsekwencji wpływa to na obniżenie trwałości konstrukcji żelbetowej, która jest zależna od właściwości betonu stanowiącego otulinę stali zbrojeniowej (Ściślewski, 1995; Bentz, Hansen, Madsen, Vallée i Griesel, 2001; Koper, Kubissa i Kubissa, 2005).

Jednym z procesów korozyjnych jest karbonatyzacja, która polega na reakcji chemicznej dwutlenku węgla $\mathrm{z}$ wodorotlenkiem wapnia. Dwutlenek węgla występuje w powietrzu oraz wodach opadowych, zaś wodorotlenek wapnia występuje w samym zaczynie. Jeśli dojdzie do reakcji między nimi, powstaje kwaśny węglan wapnia oraz woda. Prowadzi to do obniżenia $\mathrm{pH}$ betonu, a to wpływa na osłabienie ochrony stalowego zbrojenia (Neville, 2012). Proces karbonatyzacji zależy głównie od poziomu porowatości betonu, podatności na pęknięcia i powstania rys, co jest częściowo konsekwencją złej pielęgnacji.

Drugim ważnym procesem korozyjnym betonu jest korozja chlorkowa, która polega na reagowaniu chlorków ze środowiska z produktami hydratacji cementu. Proces ten przyspiesza korozję stali (Kurdowski, 2002; Glinicki, Jóźwiak-Niedźwiedzka i Marks, 2012). Taki mechanizm korozji występuje głównie w konstrukcjach drogowych oraz mających kontakt z wodą morską. Jego opis szczegółowo przedstawił Neville (2012).

\footnotetext{
$\otimes_{\text {jacek.szpetulski@pw.edu.pl }}$
} 
Na wymienione procesy korozyjne mają wpływ pośrednio następujące cechy betonu: wytrzymałość na ściskanie, nasiąkliwość i sorpcyjność masowa, które w pewnym stopniu wynikają z pielęgnacji świeżego betonu (Gemel, 2003; Kubissa, 2003). Wymienione przesłanki stały się podstawą do oceny, w jakim stopniu warunki pielęgnacji wpływają na wyniki wybranych właściwości betonu.

\section{MATERIAt I METODY}

Do realizacji badań wpływu pielęgnacji na wybrane właściwości betonu opracowano cztery składy mieszanek betonowych z udziałem kruszywa naturalnego piasku o uziarnieniu 0-2 $\mathrm{mm}$, żwiru o uziarnieniu 0-16 mm i cementu CEM II/B-V 32,5R (tab. 1).
Z każdej serii mieszanek betonowych wykonano: po 18 próbek sześciennych o krawędzi $150 \mathrm{~mm}$, po 18 próbek sześciennych o krawędzi $100 \mathrm{~mm}$ i po trzy próbki walcowe o średnicy $150 \mathrm{~mm}$ i wysokości 300 mm zgodnie z normą PN-EN 12390-1:2001. Przy wykonywaniu próbek określono klasę konsystencji mieszanek betonowych (tab. 2) według normy PN-EN 206:2014-04 na podstawie badania konsystencji metodą opadu stożka według normy PN-EN 12350-2:2001 i metoda stolika rozpływowego według normy PNEN 12350-5:2001. Próbki sześcienne i walcowe po zabetonowaniu przebywały w formach przez $24 \pm 4 \mathrm{~h}$, w temperaturze $20 \pm 1{ }^{\circ} \mathrm{C}$ i wilgotności $95 \pm 3 \%$. Po rozformowaniu próbki z każdej serii zostały podzielone na trzy grupy o oznaczeniach H, P i W (tab. 3). Każda grupa składała się z: sześciu próbek sześciennych

Tabela 1. Składy mieszanek betonowych

Table 1. Proportions of concrete mixtures

\begin{tabular}{|c|c|c|c|c|}
\hline \multirow{2}{*}{$\begin{array}{l}\text { Składy mieszanek betonowych } \\
\text { Proportions of conrete mixtures }\end{array}$} & \multicolumn{4}{|c|}{ Masa składników - Weight of components $\left[\mathrm{kg} \cdot \mathrm{m}^{-3}\right]$} \\
\hline & $\begin{array}{c}\text { Seria } 1 \\
\text { Series } 1\end{array}$ & $\begin{array}{c}\text { Seria } 2 \\
\text { Series } 2\end{array}$ & $\begin{array}{c}\text { Seria } 3 \\
\text { Series } 3\end{array}$ & $\begin{array}{l}\text { Seria } 4 \\
\text { Series } 4\end{array}$ \\
\hline Żwir - Gravel 0-16 mm & 1509 & 1349 & 1475 & 1478 \\
\hline Piasek - Sand 0-2 mm & 558 & 499 & 545 & 493 \\
\hline CEM II/B-V 32,5R & 200 & 275 & 250 & 300 \\
\hline Woda - Water & 150 & 206 & 150 & 150 \\
\hline
\end{tabular}

Tabela 2. Charakterystyka mieszanek betonowych

Table 2. Specification of concrete mixtures

\begin{tabular}{lcccc}
\hline $\begin{array}{l}\text { Specyfikacja mieszanek betonowych } \\
\text { Conrete mixtures data }\end{array}$ & \multicolumn{3}{c}{ Mieszanki betonowe - Concrete mixtures } \\
\cline { 2 - 5 } & $\begin{array}{c}\text { Seria 1 } \\
\text { Series 1 }\end{array}$ & $\begin{array}{c}\text { Seria 2 } \\
\text { Series 2 }\end{array}$ & $\begin{array}{c}\text { Seria 3 } \\
\text { Series 3 }\end{array}$ & $\begin{array}{c}\text { Seria 4 } \\
\text { Series 4 }\end{array}$ \\
\hline w/c & 0,75 & 0,75 & 0,6 & 0,5 \\
\hline $\begin{array}{l}\text { Klasa konsystencji - metoda stolika rozplywowego } \\
\text { Consistency class - the propagation table method }\end{array}$ & $\begin{array}{c}\text { brak pomiaru } \\
\text { no measure }\end{array}$ & $\mathrm{F} 4$ & $\mathrm{~F} 3$ & $\mathrm{~F} 3$ \\
\hline $\begin{array}{l}\text { Klasa konsystencji - metoda opadu stożka } \\
\text { Consistency class - slump method }\end{array}$ & $\mathrm{S} 1$ & $\mathrm{~S} 5$ & $\mathrm{~S} 1$ & $\mathrm{~S} 1$ \\
\hline
\end{tabular}

Tabela 3. Warunki pielęgnacji badanych grup betonu

Table 3. Care for the condition of tested concrete groups

\begin{tabular}{cl}
\hline Grupa - Group & \multicolumn{1}{c}{ Sposób pielęgnacji - Care method } \\
\hline \multirow{2}{*}{$\mathrm{H}$} & $\begin{array}{l}\text { próbki przebywały w temperaturze } 20 \pm 1{ }^{\circ} \mathrm{C} \text { i wilgotności } 53 \pm 3 \% \\
\text { samples were staying in temperature of } 20 \pm 1^{\circ} \mathrm{C} \text { and humidity of } 53 \pm 3 \%\end{array}$ \\
\hline \multirow{2}{*}{$\mathrm{P}$} & $\begin{array}{l}\text { próbki przebywały w temperaturze } 20 \pm 1^{\circ} \mathrm{C} \text { i wilgotności } 95 \pm 3 \% \\
\text { samples were staying in temperature of } 20 \pm 1^{\circ} \mathrm{C} \text { and humidity of } 95 \pm 3 \%\end{array}$ \\
\hline \multirow{2}{*}{$\mathrm{W}$} & $\begin{array}{l}\text { próbki przebywały w wodzie o temperaturze } 20 \pm 1^{\circ} \mathrm{C}(\mathrm{PN}-\mathrm{EN} 12390-2: 2001) \\
\text { samples were staying in water in temperature of } 20 \pm 1^{\circ} \mathrm{C}(\mathrm{PN}-\mathrm{EN} 12390-2: 2001)\end{array}$ \\
\hline
\end{tabular}


o krawędzi $150 \mathrm{~mm}$, sześciu próbek sześciennych o krawędzi $100 \mathrm{~mm}$ i jednej próbki walcowej.

Trzy próbki sześcienne o krawędzi $150 \mathrm{~mm}$ z każdego sposobu pielęgnacji dla każdej serii betonu posłużyły do oznaczenia średniej wytrzymałości na ściskanie po 28 dniach od betonowania według normy PN-EN 12390-3:2001. Wyniki z obliczeń średniej wytrzymałości na ściskanie $\left(f_{c m}\right)$ zamieszczono w tabeli 4.

Tabela 4. Średnia wytrzymałość na ściskanie próbek sześciennych o krawędzi $150 \mathrm{~mm}$

Table 4. Average compressive strength of cube with an edge of $150 \mathrm{~mm}$

\begin{tabular}{ccccc}
\hline \multirow{2}{*}{$\begin{array}{c}\text { Grupa } \\
\text { Group }\end{array}$} & $\begin{array}{c}\text { Seria 1 } \\
\text { Series 1 }\end{array}$ & $\begin{array}{c}\text { Seria 2 } \\
\text { Series 2 }\end{array}$ & $\begin{array}{c}\text { Seria 3 } \\
\text { Series 3 }\end{array}$ & $\begin{array}{c}\text { Seria 4 } \\
\text { Series 4 }\end{array}$ \\
\cline { 2 - 5 }$f_{c m}[\mathrm{MPa}]$ \\
\hline $\mathrm{H}$ & 11,5 & 11,0 & 19,5 & 28,0 \\
\hline $\mathrm{P}$ & 17,5 & 17,0 & 28,0 & 34,5 \\
\hline $\mathrm{W}$ & 19,5 & 16,5 & 31,0 & 38,5 \\
\hline
\end{tabular}

Pozostałe próbki sześcienne o krawędzi $150 \mathrm{~mm}$ z każdego sposobu pielęgnacji dla każdej serii betonu przecięto na pół i włożono do wody na 30 dni. Po upływie 58 dni od betonowania próbki zostały wyjęte $\mathrm{z}$ wody i zważone. Następnie umieszczono je w suszarce w temperaturze $95 \pm 5^{\circ} \mathrm{C}$ do osiągnięcia stałej masy. Po osiągnięciu stałej masy określono nasiąkliwość próbek z poniższego wzoru:

$n=\frac{G_{2}-G_{1}}{G_{1}} \cdot 100 \%$

gdzie:

$n$ - nasiąkliwość [\%];

$G_{1}$ - masa próbki suchej [g];

$G_{2}-$ masa próbki mokrej [g].

Połówki próbek po wykonaniu badania nasiąkliwości zostały zaizolowane na bocznych powierzchniach, aby woda mogła wnikać tylko przez jedną dolną powierzchnię i nie mogła odparowywać. Zaizolowane próbki zanurzono w naczyniu na głębokość $3 \mathrm{~mm}$ i w określonych odstępach czasowych ważono, aby określić przyrost ich masy wywołany absorpcją wody.
Proces ważenia prowadzono przez 6 h. Sorpcyjność masową $(S)$ wyznaczano jako współczynnik kierunkowy prostej wyrażającej zależność masy wchłoniętej wody $(\Delta m)$ przez powierzchnię $(F)$ od pierwiastka $\mathrm{z}$ czasu $\left(t^{-0,5}\right)$ (Banach, Kubissa, Kubissa i Pietrzak, 2012) z poniższego wzoru:

$S=\frac{\Delta m}{F \cdot t^{0,5}}$

gdzie:

$S$ - sorpcyjność masowa $\left[\mathrm{g} \cdot \mathrm{cm}^{-2} \cdot \mathrm{h}^{-0,5}\right]$;

$\Delta m$ - masa wchłoniętej wody [g];

$F$ - powierzchnia $\left[\mathrm{cm}^{2}\right]$;

$t$ - czas [h].

Trzy próbki sześcienne o krawędzi 100 mm z każdego sposobu pielęgnacji dla każdej serii betonu po 28 dniach od betonowania umieszczono w komorze wytwarzającej mgłę solną, w której zostały poddane 50 cyklom nasycania $\mathrm{NaCl}$. Na jeden cykl przypadało dwugodzinne nasolenie i czterogodzinne suszenie. Po wykonaniu 50 cykli nasycania $\mathrm{NaCl}$ próbki wyjęto z komory i przecięto na pół; powierzchnie przekroju spryskano $\mathrm{AgNO}_{3}$, pozostawiając do wyschnięcia. Po wyschnięciu na powierzchniach przekroju próbek wytrącił się biały $\mathrm{AgCl}$.

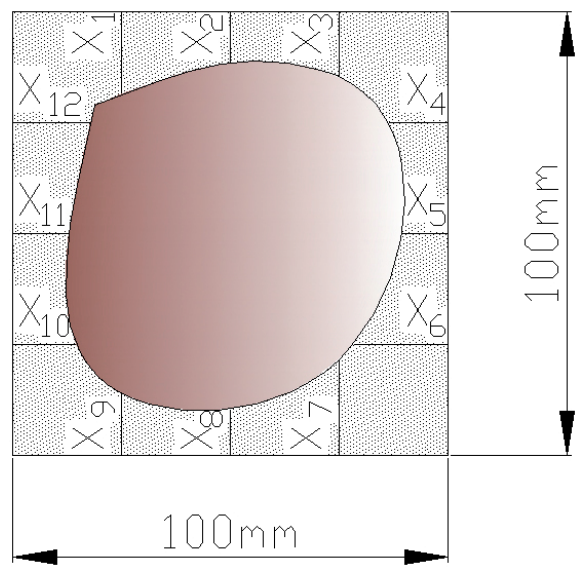

Rys. 1. Pomiary głębokości wnikania chlorków na powierzchni przekroju próbki sześciennej o krawędzi $100 \mathrm{~mm}$

Fig. 1. Measurement of chloride ions penetration depth into concrete on the surface of a cube with an edge of $100 \mathrm{~mm}$ 
Głębokość wniknięcia chlorków na powierzchni przekroju pomierzono suwmiarką w trzech punktach z każdej strony i obliczono średnią głębokość dla sześciu połówek próbek sześciennych o krawędzi 100 mm dla każdego sposobu pielęgnacji z każdej serii.

Wyznaczenie współczynnika migracji jonów chlorkowych $\mathrm{w}$ betonie przeprowadzono zgodnie $\mathrm{z}$ procedurą zawartą w NT Build 492:1999, zmieniając wymiar średnicy próbek z 100 na $150 \mathrm{~mm}$. Do przeprowadzenia badań wycięto po 28 dniach od betonowania próbki o grubości $50 \mathrm{~mm} \mathrm{z}$ warstw dolnej, środkowej i górnej wykonanych wcześniej próbek walcowych o średnicy $150 \mathrm{~mm}$ i wysokości $300 \mathrm{~mm}$. Przed badaniem próbki zostały umieszczone w komorze próżniowej na $3 \mathrm{~h}$, a następnie nasączono je nasyconym roztworem $\mathrm{Ca}(\mathrm{OH})_{2}$ przez $18 \pm 2 \mathrm{~h}$. Po nasycaniu próbki umieszczono w naczyniu pomiarowym, w którym ciecz katodowa to $100 \mathrm{~g}$ roztworu $\mathrm{NaCl}$ w $900 \mathrm{~g} \mathrm{H}_{2} \mathrm{O}$ - oddziaływała od dołu próbki, a ciecz anodowa to około $12 \mathrm{~g}$ roztworu $\mathrm{NaOH}$ w $11 \mathrm{H}_{2} \mathrm{O}$ - oddziaływała od góry próbki (rys. 2).

Temperatura próbek i obu roztworów w czasie badania wynosiła $14-24^{\circ} \mathrm{C}$. Do próbek przykładano początkowo napięcie $30 \mathrm{~V}$ i mierzono natężenie przepływającego prądu. $\mathrm{Na}$ tej podstawie dobierano $\mathrm{z}$ tabeli

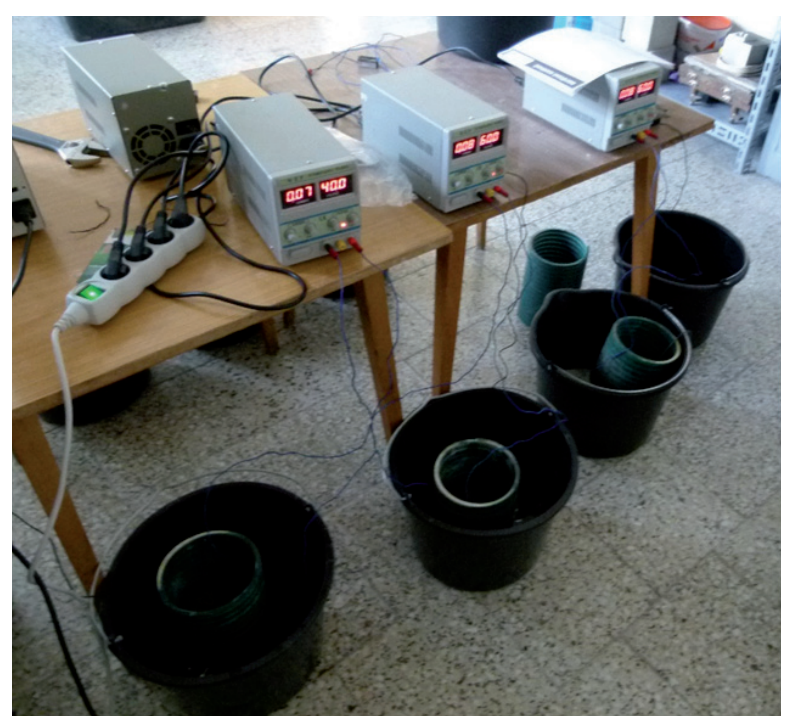

Rys. 2. Stanowisko do badania migracji jonów chlorkowych

Fig. 2. Device for researching the chloride migration coefficient umieszczonych w NT Build 492:1999 czas i napięcie prądu, przy jakim będzie prowadzone badanie. W czasie badań do próbek przyłożone były określone napięcia, które wymuszały migrację jonów chlorkowych z powierzchni zewnętrznej próbek do ich wnętrza.

Po wyjęciu z naczynia pomiarowego próbki były przecinane na pół wzdłuż średnicy, a powierzchnie przekroju były spryskiwane $\mathrm{AgNO}_{3}$. Po wyschnięciu na powierzchniach przekroju próbek wytrącił się biały $\mathrm{AgCl}$. Głębokość penetracji pomierzono w siedmiu punktach z użyciem suwmiarki (rys. 3) i na tej podstawie obliczono wartości współczynników migracji jonów chlorkowych dla każdej próbki z poniższego wzoru:

$$
\begin{aligned}
& D_{n s s m}=\frac{0,0239 \cdot(273+T) \cdot L}{(U-2) \cdot t} . \\
& \cdot\left(x_{d}-0,0238 \cdot \sqrt{\frac{(273+T) \cdot L \cdot x_{d}}{U-2}}\right)
\end{aligned}
$$

gdzie:

$D_{n s s m}-$ współczynnik migracji $\times 10^{-12}\left[\mathrm{~m}^{2} \cdot \mathrm{s}^{-1}\right]$;

$U$ - wartość przyłożonego napięcia [V];

$T$ - średnia z temperatury początkowej i końcowej $\left[{ }^{\circ} \mathrm{C}\right]$; $L$ - grubość próbki [mm];

$x_{d}$ - średnia głębokość penetracji jonów chlorkowych $[\mathrm{mm}]$;

$t$ - czas trwania badania $[\mathrm{h}]$.

Pozostałe próbki sześcienne o krawędzi 100 mm z każdego sposobu pielęgnacji dla każdej serii po 28 dniach od betonowania umieszczono w komorze do badań przyspieszonej karbonatyzacji (rys. 4) podobnie do metody opisanej w normie PN-EN 13295:2005.

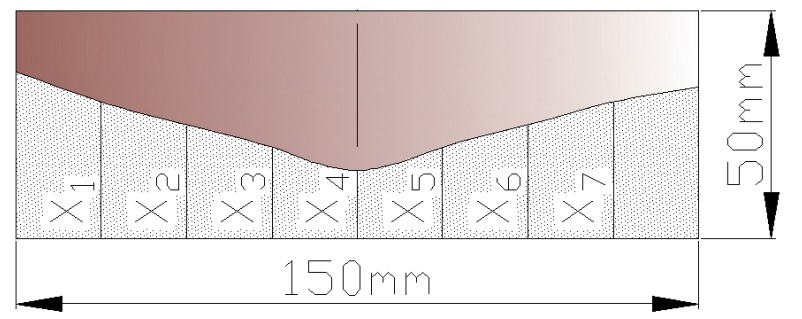

Rys. 3. Pomiary głębokości penetracji jonów chlorkowych na powierzchni przekroju próbki walcowe

Fig. 3. Depth measurement of the chloride migration coefficient into the surface of a cylindrical section 
Próbki znajdujące się w komorze, gdzie temperatura wynosiła $40 \pm 2^{\circ} \mathrm{C}$, a wilgotność $60 \pm 5 \%$, były poddane działaniu $10 \% \mathrm{CO}_{2}$ przez 28 dni. Po tym czasie próbki wyjęto z komory i przecięto na pół, a na powierzchni przekroju spryskano je jednoprocentowym roztworem fenoloftaleiny w 70-procentowym alkoholu etylowego. Po wyschnięciu na powierzchniach przekroju próbek, gdzie nie nastapiła karbonatyzacja, pojawiło się różowe zabarwienie.

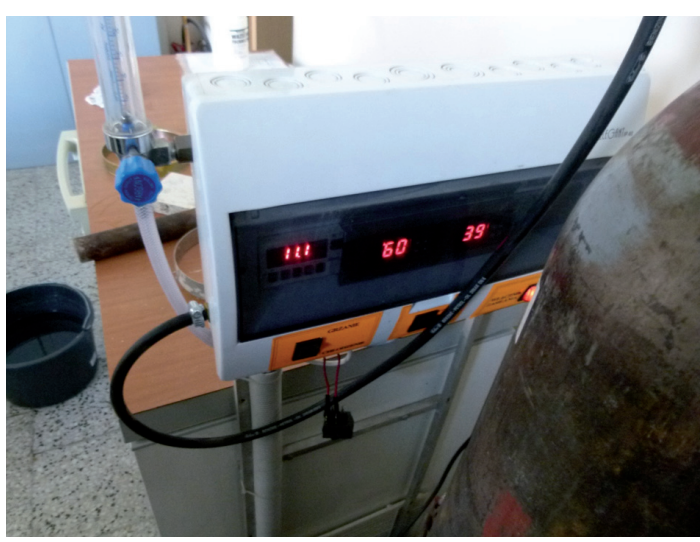

Rys. 4. Komora do badań przyspieszonej karbonatyzacji

Fig. 4. Chamber to research accelerated carbonation test

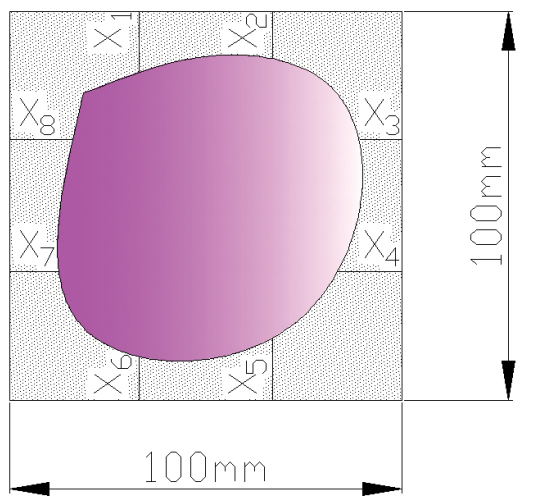

Rys. 5. Pomiary głębokości karbonatyzacji na powierzchni przekroju próbki sześciennej o krawędzi $100 \mathrm{~mm}$

Fig. 5. Depth measurement of carbonation on the surface of a cube with an edge of $100 \mathrm{~mm}$

Głębokość karbonatyzacji na powierzchni przekroju pomierzono suwmiarką $\mathrm{w}$ dwóch punktach z każdej strony i obliczono średnią głębokość dla sześciu połówek próbek sześciennych o krawędzi $100 \mathrm{~mm}$ dla każdego sposobu pielęgnacji z każdej serii.

\section{WYNIKI BADAŃ}

W tabelach 5, 6 i 7 dla różnych sposobów pielęgnacji betonu przypisano oznaczenia według tabeli 3 .

Wartości obliczeń średniej głębokości wnikania chlorków w betonowe próbki sześcienne o krawędzi 100 mm i wyniki z obliczeń współczynników migracji jonów chlorkowych na powierzchni przekroju próbek walcowych przedstawiono w odniesieniu do średniej wytrzymałości na ściskanie $\left(f_{c m}\right)$ dla każdej serii i sposobu pielęgnowania w tabeli 5 .

Wyniki z badania karbonatyzacji, nasiąkliwości i sorpcyjności masowej przedstawiono w nawiązaniu do średniej wytrzymałości na ściskanie $\left(f_{c m}\right)$ dla każdej serii i sposobu pielęgnowania $\mathrm{w}$ tabeli 5 . Wyniki z badania karbonatyzacji, nasiąkliwości i sorpcyjności masowej zmieniają się wraz ze zmianą warunków pielęgnacji.

Wpływ sposobu pielęgnacji na klasę wytrzymałości na ściskanie betonu przedstawiono $\mathrm{w}$ poniższej tabeli. Można zauważyć, że klasa wytrzymałości na ściskanie betonu zmienia się wraz ze zmianą warunków pielęgnacji.

Na wykresach słupkowych rysunków 6-10 kreskami pionowymi przedstawiono odchylenia standardowe wartości średnich dla wyników badań parametrów betonu. Na wspomnianych rysunkach oznaczenia literowe $\mathrm{H}, \mathrm{P}$ i W reprezentują sposoby pielęgnacji wedhug tabeli 3.

Na rysunkach 6 i 7 zaprezentowano wykres wpływu sposobu pielęgnacji betonu na głębokość wnikania chlorków w próbki sześcienne o krawędzi $100 \mathrm{~mm}$, które przebywały w komorze wytwarzającej mgłę solną i wykres wpływ sposobu pielęgnacji betonu na wyniki badań współczynników migracji jonów chlorkowych na powierzchni przekroju próbek walcowych. Na słupkach opisanych literami H i P odzwierciadlających rodzaj pielęgnacji znajdują się wartości procentowego wzrostu wyników wnikania chlorków w beton w stosunku do pielęgnacji oznaczonej literą W (rys. 6 i 7).

Wykresy na rysunku 6 pokazuje wyraźną zależność głębokość wnikania chlorków w próbki sześcienne o krawędzi $100 \mathrm{~mm}$ od sposobu pielęgnacji. $\mathrm{W}$ próbkach sześciennych pielęgnowanych w warunkach oznaczonych literą $\mathrm{H}$ chlorki wniknęły najgłębiej, średnio o 96\% głębiej niż w próbki pielęgnowane w wodzie, a w warunkach oznaczonych literą P o $63 \%$ 
Szpetulski, J. (2019). Wpływ sposobu pielęgnacji na wybrane właściwości betonu. Acta Sci. Pol. Architectura 18 (1), 23-32, DOI: 10.22630/ASPA.2019.18.1.3

Tabela 5. Wartości obliczeń średniej głębokości wnikania chlorków w beton ( $g$ - średnia głębokość wnikania chlorków w beton) i współczynników migracji jonów chlorkowych $\left(D_{n s s m} \times 10^{-12}\right)$

Table 5. Calculated value of average chloride penetration depth into concrete $(g-$ average chloride ions penetration depth into concrete) and chloride migration coefficients $\left(D_{n s s m} \times 10^{-12}\right)$

\begin{tabular}{|c|c|c|c|c|c|c|c|}
\hline \multirow{2}{*}{$\begin{array}{c}\text { Seria } \\
\text { Series }\end{array}$} & \multirow{2}{*}{$\begin{array}{l}\text { Grupa } \\
\text { Group }\end{array}$} & \multirow{2}{*}{$\begin{array}{c}f_{c m} \\
{[\mathrm{MPa}]}\end{array}$} & \multirow[b]{2}{*}{$\begin{array}{c}g \\
{[\mathrm{~mm}]}\end{array}$} & \multicolumn{4}{|c|}{$D_{n s s m} \times 10^{-12}\left[\mathrm{~m}^{2} \cdot \mathrm{s}^{-1}\right]$} \\
\hline & & & & $\begin{array}{l}\text { Warstwa dolna } \\
\text { Bottom layer }\end{array}$ & $\begin{array}{l}\text { Warstwa środkowa } \\
\text { Middle layer }\end{array}$ & $\begin{array}{l}\text { Warstwa górna } \\
\text { Upper layer }\end{array}$ & $\begin{array}{c}\text { Wartość średnia dla warstw } \\
\text { Average value for layers }\end{array}$ \\
\hline \multirow{3}{*}{1} & H1 & 11,5 & 25,68 & 26,99 & 36,40 & 39,99 & 34,46 \\
\hline & $\mathrm{P} 1$ & 17,5 & 20,10 & 19,38 & 33,66 & 35,97 & 29,67 \\
\hline & $\mathrm{W} 1$ & 19,5 & 12,96 & 17,18 & 24,37 & 25,89 & 22,48 \\
\hline \multirow{3}{*}{2} & $\mathrm{H} 2$ & 11,0 & 29,85 & 30,43 & 34,24 & 45,10 & 36,59 \\
\hline & $\mathrm{P} 2$ & 17,0 & 23,03 & 21,16 & 31,21 & 42,49 & 31,62 \\
\hline & $\mathrm{W} 2$ & 16,5 & 14,60 & 20,04 & 22,32 & 30,56 & 24,31 \\
\hline \multirow{3}{*}{3} & $\mathrm{H} 3$ & 19,5 & 21,07 & 25,38 & 25,59 & 35,05 & 28,67 \\
\hline & $\mathrm{P} 3$ & 28,0 & 18,76 & 17,61 & 18,83 & 26,08 & 20,84 \\
\hline & W3 & 31,0 & 11,22 & 15,89 & 19,16 & 21,23 & 18,76 \\
\hline \multirow{3}{*}{4} & $\mathrm{H} 4$ & 28,0 & 20,38 & 15,11 & 20,35 & 25,65 & 20,37 \\
\hline & P4 & 34,5 & 17,72 & 13,53 & 18,06 & 18,30 & 16,63 \\
\hline & W4 & 38,5 & 10,40 & 12,95 & 15,48 & 16,06 & 14,83 \\
\hline
\end{tabular}

Tabela 6. Wyniki badania: karbonatyzacji $(k)$, nasiąkliwości $(n)$ i sorpcyjności masowej $(S)$

Table 6. Test results: carbonation $(k)$, water absorption $(n)$, mass sorptivity $(S)$

\begin{tabular}{|c|c|c|c|c|c|}
\hline $\begin{array}{c}\text { Seria } \\
\text { Series }\end{array}$ & $\begin{array}{l}\text { Grupa } \\
\text { Group }\end{array}$ & $\begin{array}{c}f_{c m} \\
{[\mathrm{MPa}]}\end{array}$ & $\begin{array}{c}k \\
{[\mathrm{~mm}]}\end{array}$ & $\begin{array}{c}n \\
{[\%]}\end{array}$ & $\begin{array}{c}S \\
{\left[\mathrm{~g} \cdot \mathrm{cm}^{-2} \cdot \mathrm{h}^{-0,5}\right]}\end{array}$ \\
\hline \multirow{3}{*}{1} & H1 & 11,5 & w całym przekroju - throughout the cross-section & 5,33 & 0,274 \\
\hline & $\mathrm{P} 1$ & 17,5 & w całym przekroju - throughout the cross-section & 5,33 & 0,185 \\
\hline & W1 & 19,5 & 29,40 & 5,31 & 0,117 \\
\hline \multirow{3}{*}{2} & $\mathrm{H} 2$ & 11,0 & w całym przekroju - throughout the cross-section & 7,21 & 0,414 \\
\hline & $\mathrm{P} 2$ & 17,0 & 37,40 & 7,57 & 0,240 \\
\hline & W2 & 16,5 & 27,29 & 7,47 & 0,159 \\
\hline \multirow{3}{*}{3} & $\mathrm{H} 3$ & 19,5 & 29,50 & 5,20 & 0,152 \\
\hline & $\mathrm{P} 3$ & 28,0 & 24,17 & 5,16 & 0,141 \\
\hline & W3 & 31,0 & 15,77 & 5,25 & 0,098 \\
\hline \multirow{3}{*}{4} & $\mathrm{H} 4$ & 28,0 & 16,58 & 5,32 & 0,104 \\
\hline & $\mathrm{P} 4$ & 34,5 & 15,29 & 5,41 & 0,097 \\
\hline & W4 & 38,5 & 10,00 & 5,15 & 0,086 \\
\hline
\end{tabular}

Tabela 7. Klasy wytrzymałość na ściskanie próbek sześciennych o krawędzi $150 \mathrm{~mm}$ pielęgnowanych różnymi sposobami

Table 7. Classes of compressive strength of a cube with an edge of $150 \mathrm{~mm}$ in different ways of care

\begin{tabular}{|c|c|c|c|c|c|c|c|c|c|c|c|c|}
\hline \multirow{2}{*}{$\begin{array}{l}\text { Grupa } \\
\text { Group }\end{array}$} & \multicolumn{3}{|c|}{ Seria $1-$ Series 1} & \multicolumn{3}{|c|}{ Seria 2 - Series 2} & \multicolumn{3}{|c|}{ Seria 3 - Series 3} & \multicolumn{3}{|c|}{ Seria 4 - Series 4} \\
\hline & $\begin{array}{c}f_{c m} \\
{[\mathrm{MPa}]}\end{array}$ & $\begin{array}{c}f_{c, \text { min }} \\
{[\mathrm{MPa}]}\end{array}$ & $\begin{array}{l}\text { Klasa } \\
\text { Class }\end{array}$ & $\begin{array}{c}f_{c m} \\
{[\mathrm{MPa}]}\end{array}$ & $\begin{array}{c}f_{c, \text { min }} \\
{[\mathrm{MPa}]}\end{array}$ & $\begin{array}{l}\text { Klasa } \\
\text { Class }\end{array}$ & $\begin{array}{c}f_{c m} \\
{[\mathrm{MPa}]}\end{array}$ & $\begin{array}{c}f_{c, \text { min }} \\
{[\mathrm{MPa}]}\end{array}$ & $\begin{array}{l}\text { Klasa } \\
\text { Class }\end{array}$ & $\begin{array}{c}f_{c m} \\
{[\mathrm{MPa}]}\end{array}$ & $\begin{array}{c}f_{c, \min } \\
{[\mathrm{MPa}]}\end{array}$ & $\begin{array}{l}\text { Klasa } \\
\text { Class }\end{array}$ \\
\hline $\mathrm{H}$ & 11,5 & 11,27 & $\begin{array}{l}\text { brak } \\
\text { none }\end{array}$ & 11,0 & 10,73 & $\begin{array}{l}\text { brak } \\
\text { none }\end{array}$ & 19,5 & 19,20 & $\mathrm{C} 12 / 15$ & 28,0 & 27,63 & $\mathrm{C} 16 / 20$ \\
\hline $\mathrm{P}$ & 17,5 & 17,38 & $\mathrm{C} 8 / 10$ & 17,0 & 16,27 & $\mathrm{C} 8 / 10$ & 28,0 & 27,71 & $\mathrm{C} 16 / 20$ & 34,5 & 33,67 & $\mathrm{C} 25 / 30$ \\
\hline $\mathrm{W}$ & 19,5 & 19,10 & $\mathrm{C} 12 / 15$ & 16,5 & 15,93 & $\mathrm{C} 8 / 10$ & 31,0 & 30,69 & C20/25 & 38,5 & 38,30 & $\mathrm{C} 25 / 30$ \\
\hline
\end{tabular}




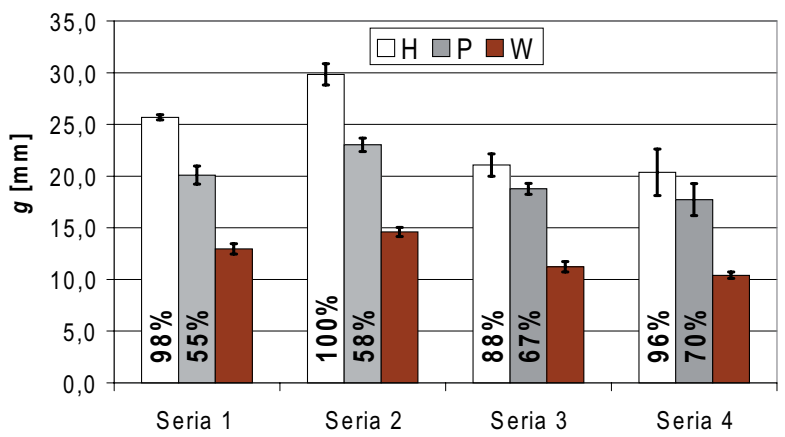

Rys. 6. Wykres wyników z pomiaru głębokości wnikania chlorków $(g)$ w próbki sześcienne o krawędzi $100 \mathrm{~mm}$ pielęgnowanych różnymi sposobami

Fig. 6. Chart results of chloride ions penetration depth into a cube with an edge of $100 \mathrm{~mm}$ in different ways of care

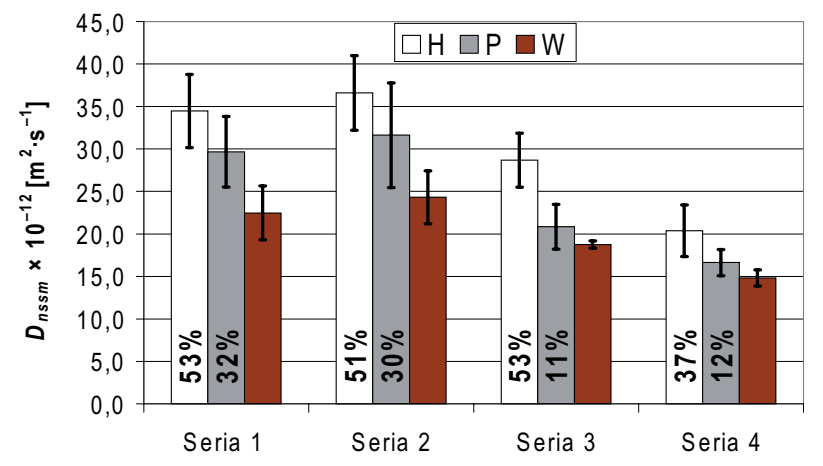

Rys. 7. Wykres wyników z badań współczynników migracji $\left(D_{n s s m} \times 10^{-12}\right)$ jonów chlorkowych na powierzchni przekroju próbek walcowych pielęgnowanych różnymi sposobami

Fig. 7. Chart results of the chloride migration coefficient test into a cylindrical surface in different ways of care

głębiej. W badaniu współczynników migracji jonów chlorkowych największy wzrost wartości tego parametru odnotowano dla próbek przebywających w warunkach o najmniejszej wilgotności (grupa $\mathrm{H}$ ), a najmniejszymi wartościami charakteryzowały się próbki pielęgnowane w wodzie (grupa W).

Na rysunku 8 przedstawiono wykres wpływu sposobu pielęgnacji betonu na badanie karbonatyzacji na próbkach sześciennych o krawędzi $100 \mathrm{~mm}$. W serii 1 próbki pielęgnowane $\mathrm{w}$ warunkach oznaczonych literami $\mathrm{H}$

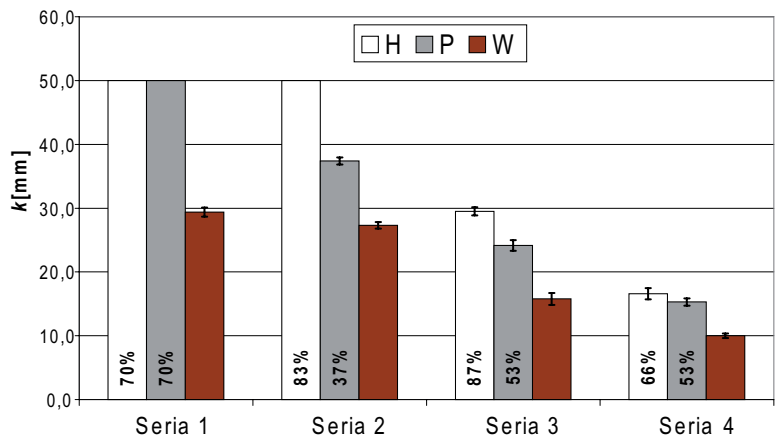

Rys. 8. Wykres wyników z badań karbonatyzacji $(k)$ na próbkach sześciennych o krawędzi $100 \mathrm{~mm}$ pielęgnowanych różnymi sposobami

Fig. 8. Chart results of carbonation $(k)$ test into a cube with an edge of $100 \mathrm{~mm}$ in different ways of care

i P uległy procesowi karbonatyzacji w całym przekroju, a w serii 2 tylko próbki pielęgnowane w warunkach oznaczonych literą $\mathrm{H}$ uległy procesowi karbonatyzacji w całym przekroju. Na słupkach opisanych literami H i P odzwierciadlających rodzaj pielęgnacji znajdują się wartości procentowego wzrostu wyników pomiaru głębokości karbonatyzacji w stosunku do pielęgnacji oznaczonej literą W. Zatem średnie wartości procentowego wzrostu głębokości karbonatyzacji dla grupy betonu $\mathrm{H}$ wynoszą $77 \%$, a dla grupy betonu $\mathrm{P}$ stanowią $53 \%$.

Na rysunkach 9 i 10 pokazano wykres wpływu sposobu pielęgnacji betonu na wyniki badania nasiąkliwości i sorpcyjności masowej na próbkach sześciennych o krawędzi $150 \mathrm{~mm}$. Na wykresach słupkowych opi-

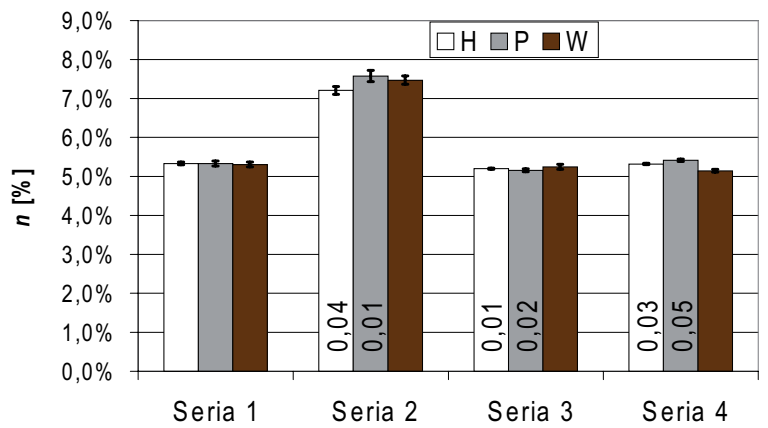

Rys. 9. Wykres wyników z badania nasiąkliwości ( $n$ ) na próbkach sześciennych o krawędzi $150 \mathrm{~mm}$ pielęgnowanych różnymi sposobami

Fig. 9. Chart results of water absorption test into a cube with an edge of $150 \mathrm{~mm}$ in different ways of care 


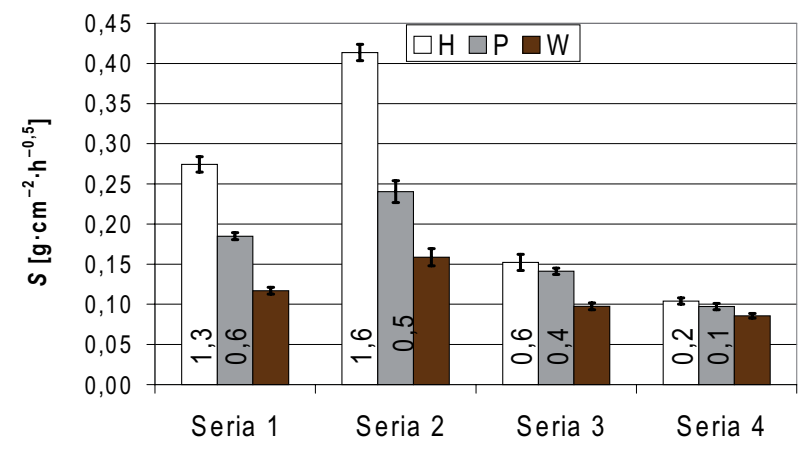

Rys. 10. Wykres wyników z badania sorpcyjności masowej (S) na próbkach sześciennych o krawędzi $150 \mathrm{~mm}$ pielęgnowanych różnymi sposobami

Fig. 10. Chart results of mass sorptivity test into a cube with an edge of $150 \mathrm{~mm}$ in different ways of care

sanych literami H i P umieszczono wartości, które ilustrują, w jakim stopniu zmieniły się wyniki z badania nasiąkliwości i sorpcyjności masowej względem pielęgnacji oznaczonej literą W.

Nie zaobserwowano znaczących zmian nasiąkliwości od sposobu pielęgnacji (rys. 9), zaś wzrost sorpcyjności masowej wraz z pogorszeniem się warunków pielęgnacji jest wyraźnie widoczny (rys. 10).

Na podstawie przeprowadzonej analizy wpływu sposobu pielęgnacji na wybrane właściwości betonu sporzą- dzono tabelę podsumowującą (tab. 8), w której zamieszczono procentowe zmiany wyników z przeprowadzonych badań betonu $\mathrm{z}$ pielęgnacji oznaczonych literami $\mathrm{H}$ i P w stosunku do pielęgnacji oznaczonej literą W.

W większym stopniu uległy pogorszeniu właściwości betonu pielęgnowanego $\mathrm{w}$ warunkach o małej wilgotności (53\%) niż w warunkach dużej wilgotności (95\%). Próbki przechowywane w wodzie miały najkorzystniejsze prawie wszystkie badane parametry.

\section{PODSUMOWANIE}

W celu oceny sposobu pielęgnacji na wybrane właściwości betonu z kruszywem naturalnym wykonano badania wytrzymałości na ściskanie, wnikania chlorków w beton (pomiar głębokości wnikania chlorków oraz wyznaczenie współczynników migracji jonów chlorkowych), karbonatyzacji, nasiąkliwości i sorpcyjności masowej.

Sposoby pielęgnacji betonu przyczyniły się do zróżnicowania struktury betonu i w wyniku tego zmieniły się jego właściwości: wytrzymałość na ściskanie, skłonność do wnikania chlorków i głębokości karbonatyzacji, nasiąkliwość, sorpcyjność masowa.

Przebywanie próbek wykonanych serii betonu w warunkach najmniejszej wilgotności spowodowało

Tabela 8. Stopień wpływu pielęgnacji oznaczonych literami H i P na wybrane właściwości betonu w stosunku do pielęgnacji oznaczonej literą W: $g$ - głębokość wnikania chlorków w beton, $D_{n s s m} \times 10^{-12}-$ współczynnik migracji jonów chlorkowych, $k$ - karbonatyzacja, $n$ - nasiąkliwość, $S$ - sorpcyjność masowa

Table 8. The degree of impact on maintenance marked with letters $\mathrm{H}$ and $\mathrm{P}$ on selected concrete properties compared with maintenace marked with letter W: $g$ - chloride ions penetration depth into concrete, $D_{n s s m} \times 10^{-12}-$ chloride migration coefficient, $k$ - carbonation, $n$ - water absorption, $S$ - mass sorptivity

\begin{tabular}{|c|c|c|c|c|c|c|}
\hline $\begin{array}{l}\text { Grupa } \\
\text { Group }\end{array}$ & $\begin{array}{l}\text { Seria } \\
\text { Series }\end{array}$ & $\begin{array}{c}g \\
{[\mathrm{~mm}]}\end{array}$ & $\begin{array}{c}D_{n s s m} \times 10^{-12} \\
{\left[\mathrm{~m}^{2} \cdot \mathrm{s}^{-1}\right]}\end{array}$ & $\begin{array}{c}k \\
{[\mathrm{~mm}]}\end{array}$ & $\begin{array}{c}n \\
{[\%]}\end{array}$ & $\begin{array}{c}S \\
{\left[\mathrm{~g} \cdot \mathrm{cm}^{-2} \cdot \mathrm{h}^{-0,5}\right]}\end{array}$ \\
\hline \multirow{4}{*}{$\mathrm{H}$} & 1 & $98 \%$ & $53 \%$ & $70 \%$ & brak & 1,3 \\
\hline & 2 & $100 \%$ & $51 \%$ & $83 \%$ & $0,04 \downarrow$ & 1,6 \\
\hline & 3 & $88 \%$ & $53 \%$ & $87 \%$ & $0,01 \downarrow$ & 0,6 \\
\hline & 4 & $96 \%$ & $37 \%$ & $66 \%$ & $0,03 \uparrow$ & 0,2 \\
\hline \multirow{4}{*}{$\mathrm{P}$} & 1 & $55 \%$ & $32 \%$ & $70 \%$ & brak & 0,6 \\
\hline & 2 & $58 \%$ & $30 \%$ & $37 \%$ & $0,01 \uparrow$ & 0,5 \\
\hline & 3 & $64 \%$ & $11 \%$ & $53 \%$ & $0,02 \downarrow$ & 0,4 \\
\hline & 4 & $70 \%$ & $12 \%$ & $53 \%$ & $0,05 \uparrow$ & 0,1 \\
\hline
\end{tabular}


największe pogorszenie badanych właściwości betonu. W seriach 1 i 2 średnia wytrzymałość na ściskanie zmniejszyła się w takim stopniu, że wytrzymałość nie osiągnęła poziomu najniższej klasy betonu według normy PN-EN 206:2014-04.

Przebywanie próbek wykonanych serii betonu w wilgotności $95 \pm 3 \%$ spowodowało pogorszenie właściwości betonu, ale nie w tak dużym stopniu, jak w próbkach przechowywanych $\mathrm{w}$ temperaturze $20 \pm 1{ }^{\circ} \mathrm{C}$ i wilgotności $53 \pm 3 \%$ (grup $\mathrm{H}$ ). W seriach 1 i 3 wyznaczone według nomy PN-EN 206:2014-04 klasy wytrzymałości na ściskanie obniżyły się o jedną klasę w stosunku do próbek przebywających w wodzie.

Na wymienione właściwości betonu miał prawdopodobnie wpływ także skład mieszanek betonowych, wartość współczynnika w/c oraz zawartość cementu.

Wpływ sposobu pielęgnacji nie jest zauważalny w badaniu nasiąkliwości, dlatego właściwe jest przeprowadzanie badań sorpcyjności masowej, w których wpływ sposobu pielęgnacji jest wyraźny. Dla betonu pielęgnowanego $\mathrm{w}$ warunkach suchych (grupa $\mathrm{H}$, serie 1 i 2) w bardzo dużym stopniu ulega pogorszeniu sorpcyjność masowa, która wpływa na jakość otuliny ochronnej dla stali zbrojeniowej.

\section{ADNOTACJA}

Badania zostały wykonane na Wydziale Budownictwa, Mechaniki i Petrochemii Politechniki Warszawskiej, w Centralnym Laboratorium Instytutu Budownictwa i w Laboratorium Badawczym Innowacyjnych Technologii i Materiałów, którego budowa była współfinansowana ze środków Europejskiego Funduszu Rozwoju Regionalnego w ramach Regionalnego Programu Operacyjnego Województwa Mazowieckiego 2007-2013

\section{PIŚMIENNICTWO}

Banach, M., Kubissa, J., Kubissa, W. i Pietrzak, K. (2012). O metodach pomiaru sorpcyjności betonu. Inżynieria i Budownictwo, 11, 596-598.
Bentz, D. P., Hansen, K. K., Madsen, H. D., Vallée, F. i Griesel, E. J. (2001). Drying/Hydration in Cement Pastes During Curing. Materials and Structures, 34 (9), $557-565$

Gemel, P. (2003). O właściwej pielęgnacji. Budownictwo, Technologie, Architektura, 2 (0), 62.

Glinicki, M. A., Jóźwiak-Niedźwiedzka, D. i Marks, M. (2012). Automatic categorization of chloride migration into concrete modified with $\mathrm{CFBC}$ ash. Computers and Concrete, 5, 375-387.

Jamroży, Z. (2015). Beton i jego technologie. Warszawa: Wydawnictwo Naukowe PWN.

Koper, W., Kubissa, J. i Kubissa, W. (2005). Wpływ pielęgnacji na właściwości betonu związane $\mathrm{z}$ trwałością konstrukcji. Przeglad Budowlany, 76 (3), 20-24.

Kubissa, W. (2003). Wpływ pielęgnacji na wybrane właściwości betonu. Inżynieria i Budownictwo, 59 (6), 341342 .

Kurdowski, W. (2002). Korozja chlorkowa betonu. CementWapno - Beton, 7/69 (2), 56-60.

Neville, A. M. (2012). Właściwości betonu. Kraków: Wydawnictwo Stowarzyszenia Producentów Cementu.

NT Build 492:1999. Chloride migration coefficient from non-steady-state migration experiments.

PN-EN 12350-2:2001. Badania mieszanki betonowej. Część 2: Badanie konsystencji metodą opadu stożka.

PN-EN 12350-5:2001. Badania mieszanki betonowej. Część 5: Badanie konsystencji metodą stolika rozpływowego.

PN-EN 12390-1:2001. Badania betonu. Część 1: Kształt, wymiary i inne wymagania dotyczące próbek do badania i form.

PN-EN 12390-3:2001. Badania betonu. Część 3: Wytrzymałość na ściskanie próbek do badania.

PN-EN 13295:2005. Wyroby i systemy do ochrony i napraw konstrukcji betonowych. Metody badań. Oznaczanie odporności na karbonatyzacji.

PN-EN 206:2014-04. Beton. Część 1: Wymagania, właściwości, produkcja i zgodność.

Ściślewski, Z. (1995). Trwałość konstrukcji żelbetowych. Warszawa: Wydawnictwo Instytutu Techniki Budowlanej.

Ściślewski, Z. (1999). Ochrona konstrukcji żelbetowych. Warszawa: Arkady. 


\section{IMPACT OF CARE ON SELECTED CONCRETE PROPERTIES}

\section{ABSTRACT}

The method of care contributes to the change of the concrete structure, and as a result, its properties change. The article presents the impact of three different ways of care on concrete properties. This study considers the results of three different approaches to care on concrete properties. The study looks at the effects of the concrete care methods on compressive strength, chloride penetration into concrete, carbonation and water absorption, and sorptivity tests were carried out. On the basis of the performed tests, it can be concluded that the care of concrete in conditions of low humidity at the level of $53 \%$ causes a significant deterioration of the concrete properties.

Key words: concentrate care, compressive strength, chlorides penetration into concrete, carbonation, water absorption and sorptivity 